\title{
Understanding the Energy System of the Paulista Macrometropolis: first step in local action toward climate change
}

\author{
Flávia Mendes de Almeida Collaço \\ Raiana Schirmer Soares \\ João Marcos Mott Pavanelli \\ Lira Luz Benites-Lazaro \\ Guilherme Massignan Berejuk \\ Andrea Lampis \\ Célio Bermann
}

${ }^{I}$ School of Arts, Sciences and Humanities (EACH-USP, São Paulo, SP, Brasil.

D Institute of Energy and Environment (IEE-USP), São Paulo, SP, Brasil.

III School of Arts, Sciences and Humanities (EACH-USP, São Paulo, SP, Brasil.

(D) IV Faculty of Public Health (FSPUSP), São Paulo, SP, Brasil.

(D) ${ }^{\mathrm{V}}$ Institute of Energy and Environment (IEE-USP), São Paulo, SP, Brasil.

${ }^{\mathrm{V}}$ Institute of Energy and Environment (IEE-USP), São Paulo, SP, Brasil.

D ${ }^{\mathrm{VII}}$ Institute of Energy and Environment (IEE-USP), São Paulo, SP, Brasil.
Abstract: This paper analyzes the historical trends in the energy supply and demand for the Macrometrópole Paulista Energy System, as well as the existing options for harnessing the renewable energy potential of the region. The research included a case study covering the 174 municipalities that belong to the macro-metropolis to characterize the energy system from 2006 to 2017 while analyzing the CO2 emissions of the system. The results indicated that, in 2017, the Paulista macro-metropolis accounted for $73 \%$ of the total energy demand of the entire state of São Paulo. Moreover, considering the energy generated from within the administrative limits of the 174 municipalities, the macro-metropolis accounted for about $17 \%$ of the total installed capacity of the state for electricity generation. This study found that the installed capacity for electricity generation in the region can be increased by $\sim 112 \%$. There so, an understanding of the local energy systems is of utmost importance for the formulation of coherent and integrated public policies, which are necessary to cope with the effects of climate change.

Keywords: Energy System; Paulista Macrometropolis; Climate Change; Energy Governance.

São Paulo. Vol. 23, 2020

Feature Topics: Urbanization, Planning and Climate Change

DOI: http://dx.doi.org/10.1590/1809-4422asoc0176r1vu2020L6TD 


\section{Introduction}

The Paris Agreement (2015) recognizes adaptation to climate change as a global challenge, with local, subnational, national, regional, and international dimensions. For this reason, implementing measures to mitigate and adapt to climate change involves recognizing a cross-border view of climate risk and the interconnections between people, ecosystems, and economies in a globalized world (DAVIS; BENZIE; BARROTT, 2016). This is particularly important because the impacts of climate change will be significantly felt at the regional and local levels (IPCC, 2014). Thus, given that local governments have many of the skills needed to implement political actions, they play key roles in climate negotiations (SCHAKEL; HOOGHE; MARKS, 2015; SELLERS; SUN-YOUNG, 2011). However, the presence of a certain degree of uncertainty with regard to the scope and breadth of political actions alters the modus operandi of the formulation, implementation, and monitoring of traditional public policies. This increases the complexity and nature of the challenges associated with adapting to climate change and creates opportunities to reinvigorate international cooperation and rethink energy governance, both locally and globally.

In this sense, Urban Energy Planning (UEP), as well as Urban Energy Systems (UES), are topics that have attracted growing research interest. They constitute a research area with great potential to identify means to achieve the development of sustainable and low-carbon cities. In this context, this study aims to describe and analyze the energy system in the region of the Paulista macro-metropolis (MMP) in São Paulo State, Brazil. Data on the supply and demand of energy were collected for 2006-2017. Parallelly, options for the incentivization and better exploitation of renewable sources (RES) to generate electricity were also analyzed.

To do so, the paper poses the following research questions: What are the most consumed energy resources and the most demanding economic sectors in the MMP? What are the compositions of RES and nonrenewable consumption, given the demand and supply of this region? What is the MMP estimate of greenhouse gas (GHG) emissions? What is the potential of RES in increasing energy generation in each of the MMP municipalities?

In order to answer these questions, the study analyzed 174 municipalities that constitute the MMP to identify the energy systems (ES) of these municipalities. This research analyzed data on i) the energy demand of each municipality (2006-2017); ii) the energy supply, considering the installed capacity (in $\mathrm{kW}$ ) for electricity generation in the region (until June 2019); iii) estimation of the capacity to take advantage of local renewable resources possibilities, such as the photovoltaic and hydraulic, for electricity generation through the identification of the unrealized potential of small hydroelectric powerplants (SHPs) and biogas (including sewage waste converted to sludge); and iv) the historic $\mathrm{CO} 2$ emissions in the MMP from government records.

Next section presents a review of a set of themes that are important to the development of the study: Energy, Energy Governance and Climate Change. The "Renewable energy sources, distributed generation, and local action" section discusses the technical aspects of RES, distributed generation, and local action. The "materials and methods" 
section characterizes the MMP and describes the methodology followed. The "results" section presents and discusses the relevance of the energy demand and supply in the region. The concluding section highlights the achievements and limitations of this study and presents suggestions for future research

\section{Energy, Energy Governance and Climate Change}

According to El Baradei (2008), "access to energy is a fundamental condition to provide development and economic growth." However, in developing countries, such as Brazil, the relationship between economic growth and development needs to be analyzed with greater care. Undoubtedly, energy use is strongly related to almost all aspects of development, including income, health, nutrition, water, infrastructure, education, and life expectancy. However, energy production and consumption are associated with an increase in the global inequalities and environment deterioration too. The latter is a result of the use of fossil fuels from mostly industrial, agricultural, commercial, and residential systems that were built based on "black gold" (BENITES-LAZARO et al., 2018a; URRY, 2010). At present, the production and consumption of energy is the largest source of global GHG emissions (BALAT, 2005; BAZILIAN et al., 2014; REHMAN; RASHID, 2017). According to the International Agency of Energy (IEA), climate change is closely associated with anthropogenic emissions of $\mathrm{CO}$, two-thirds of which come from the production and use of energy (IEA, 2015).

Even though the relationship between global energy consumption and climate change has received much attention, the performance and implementation of policies are limited. Likewise, the environmental impact of current energy systems has received insufficient recognition. According to Heubaum and Biermann (2015), for many years, climate conventions did not address the problems of climate change with the use of energy. In recent years, however, a large number of governments have set national targets for reducing GHG emissions, especially under the Paris Agreement (2015). Furthermore, only a few countries have managed to design and successfully implement an energy policy in line with the urgent need to decarbonize their economies (HEUBAUM; BIERMANN, 2015; VAN DE GRAAF; COLGAN, 2016).

According to some scholars, the problem is worsened by the institutional architecture of the global energy governance, which remains highly fragmented and ill-equipped to effectively address the polycentrism inherent of the field (ESCRIBANO, 2015). This lack of effective governance is associated with a variety of interconnected and highly complex problems, such as the need for energy security, access to different energy sources, and the negative environmental and climatic externalities created by the extraction, production, transportation, and consumption of energy (HEUBAUM; BIERMANN, 2015).

Allen, Dávila, and Hoffman (2005) emphasized how the debate on governance has notably expanded over the last fifteen years. They associated this expansion with a growing interest by the international community for understanding and improving the general conditions to formulate efficient policies for combining participatory democracies, 
social justice, and environmental sustainability (ALLEN; DAVILA; HOFMANN, 2005). Thus, this work assumes the definition of energy governance, proposed by Sovacool and Florini (2012); according to them, energy governance is a structure that encompasses regulation and law enforcement to overcome the problems of collective action related to the supply and use of energy. It involves the processes of scheduling, negotiating, implementing, monitoring, and applying energy-related laws and agreements at different scales (local, national, and global) as well as energy actors, including governments, nongovernmental organizations (NGOs), civil society groups, corporations, public-private partnerships, and ordinary consumers.

Multilevel governance has become a standard tool to explain how climate and energy actions operate within polycentric, multisectoral, and multi-stakeholder political settings. The mechanisms are generally identified within the transfer of competences between local, national, and inter-governmental institutions (KERN; BULKELEY, 2009; WESTMAN; BROTO; HUANG, 2019; FUHR; HICKMANN; KERN, 2018). This implies that local climate actions have become increasingly integrated into regional, national, and international policy frameworks (GREGORIO, et al., 2019) . Thus, multilevel climate governance essentially means activating the dynamic potential of each government as well as increasing the degree of interaction between different levels of governments to achieve a global mobilization of actors (JÄNICKE; QUITZOW, 2017).

Several studies have analyzed multilevel governance models related to the climate change, primarily focusing on the involvement of cities and local governments (MELICA, et al., 2018; FUHR; HICKMANN; KERN, 2018). In addition, several international organizations have highlighted the vital role of local governments in the global response to climate change. Recently, several initiatives have been launched at the international level, one of the most important being the United Nations New Urban Agenda for Habitat (UNITED NATIONS HABITATS, 2017). Such an agenda provides a guiding framework for national governments to support sustainable urbanization. Recent studies show that cities have optimal socioeconomic and regulatory conditions that make the local level an ideal locus for coordinating all the possible responses to the problem of developing more effective policies regarding environmental and energy issues (WESTMAN; BROTO; HUANG, 2019; FUDGE; PETERS, 2016).

\section{Renewable energy sources, distributed generation and local action}

As stated in the previous section, the lack of governance at global and national levels has contributed to the strengthening of the role of cities as agents of sustainability and resilience during climate threats (JACOBI; TRANI, 2019). The potential contributions of the municipalities to the implementation of mitigation and adaptation strategies are recognized in the light of an UES perspective. Accordingly, there is a need for cooperation between policies, different levels of government, and the public sector.

The different types of energy sources can be divided into RES and nonrenewable energy sources. Some examples of nonrenewable resources include oil and oil products 
(fossil fuels) that are the main factor associated with climate change (WEBB; HAWKEY; TINGEY, 2016). Examples of RES sources are biomass, biogas, hydro, sun, wind, and nuclear (GOLDEMBERG; LUCON, 2012). Both renewable and nonrenewable sources are used in the provision of energy services (e.g., driving force, lighting, process heat, direct heating, and cooling); they are also used to generate electricity. Therefore, understanding the needs, the end uses of energy, and the potential of offering service within the limits of the municipalities constitute the initial part of the research for proposing contextualized public policies to adapt and mitigate the climate change within cities.

Similarly, investing in distributed generation can be considered a form of local action in the energy field, i.e., the exploitation of renewable resources can occur according to centralized strategies (i.e., traditional energy planning) or distributed strategies (i.e., characterized by allowing energy generation that is close to final energy consumers, regardless of the power, technology, or source used). Examples of distributed energy sources are sun, wind, biogas, biomass, water, and cogeneration. Despite this, the most widely used distributed renewable energy in Brazil is solar photovoltaic (PV; ANEEL, 2019b) energy, and in a centralized way, wind and solar photovoltaic (PV) (EPE, 2018).

However, there are a few problems associated with the electricity generated by such sources (i.e., solar and wind); if the supply is not immediately followed by the consumption, the dispatch of electricity on the grid becomes difficult to control. The intermittent availability of sources also poses challenges. Climatic and meteorological conditions determine the frequency and intensity of the winds and the solar incidence (PEREIRA et al., 2017). In fact, non-renewable fuels, such as natural gas (NG), oil, coal and water used for hydroelectric power, can be stored (in this case, reducing energy intermittency). A large water dam or barrels of stored oil guarantees the stable on-demand electricity generation (LOVINS, 2013). In the case of PV and wind sources, this predictive capacity becomes more fluid and generation is subjected to short-term meteorological aspects (PRASAD; TAYLOR; KAY, 2017).

Several studies are being conducted to incorporate RES into the electricity grid worldwide. When studying the synergy between PV and the wind, Prasad, Taylor, and Kay (2017) demonstrated that there is synergistic potential for the use of spacetime between wind generation and photovoltaic solar generation in an associated manner, including reducing their production costs. Other studies (CARRASCO et al., 2004; LEHTOLA; ZAHEDI, 2019; LIANG; MAZIN; REZA, 2017; NOTTON et al., 2018; ROSLAN et al., 2019) have also revealed the limitations of photovoltaic, solar, or wind energy in electricity grid operation.

Recent studies (GIROTTI, 2019; MARINS, 2014) have demonstrated the importance of analyzing the locally distributed energy sources together with the land use municipalities situation. Exploring the possibilities of using renewables in a distributed manner allows the involvement and input of local governments in energy planning; these practices may increase the generation efficiency and reduce the impact on the electricity grid. Commercial or mixed land-use, when associated with the distributed photovoltaic generation, is a UEP strategy that reduces the electrical intermittency problem associated 
with the use of distributed generation. Most of the time, the peak in energy consumption in the commercial sector occurs together with the PV generation in buildings.

As pointed out, the energy supply from RES may be limited by the intermittency of sources, such as sun and wind. If not correctly handled it can cause an imbalance between supply and demand. These limitations, however, can be overcome, since updated studies (e.g., LIANG; MAZIN; REZA, 2017; NOTTON et al., 2018; ROSLAN et al., 2019) area addressing methods for estimating the impact of different storage devices, energy planning decentralization, and the association of energy planning with urban planning in order to reduce the limitations pointed out. As RES are found across wide landscapes, the research exploring their incorporation into energy distribution systems is expanding. In this respect, there is a need to urgently address: the understand of the composition of the supply and demand for energy in urban and rural areas; and, the potential for local energy generation using local RES.

Lastly, multilevel governance is presented in this paper as a perspective to study socio-technical transitions; by recognizing the regime transitions complexity that involve multidimensional interactions that are constantly evolving between various actors, such as governments, industries, technological entities, markets, cultures, and society (GEELS; KEMP, 2012). Likewise, they involve power relations, as shown by Soares (2020), which captures a positive correlation between indicators, such as the distributed photovoltaic generation facilities at the MMP level, different municipal human development indexes (MHDI), and the average income per capita of the municipalities. Therefore, this source of energy is available only to a restricted population, having greater purchasing power (SOARES, 2020; COLLAÇO et al., 2019b).

\section{Materials and methods}

\section{Characterization of the Macrometropolis Paulista}

The MMP is an area of continuous expansion that constitutes different territorial units. A total of 174 municipalities (EMPLASA, 2012) are distributed in 4 metropolitan regions (São Paulo, Baixada Santista, Campinas, Paraíba Valley, and North Coast), 3 urban areas (Jundiaí, Piracicaba, and Sorocaba), and 2 microregions (São Roque and Bragantina; EMPLASA, 2012).

It is possible to verify the growth of the MMP through a brief description and historical analysis of three indicators of the region: territorial extension, population, and the gross domestic product (GDP). In 2012, the MMP covered an area of 49,927 km2 (EMPLASA, 2012). Currently, this area has grown to $53,400 \mathrm{~km} 2$ (EMPLASA, 2019).

In 2010, there were 30 million inhabitants in MMP (EMPLASA, 2012); today, it is estimated to around 32 million (SEADE, 2019). In 2009, GDP of the region was R\$ 897,419,430 (EMPLASA, 2012); it reached R $\$ 1,669,448,647$ in 2016 (IBGE, 2019). Finally, the region is of substantial economic importance, accounting for $80 \%$ of the state GDP and almost 30\% of the national GDP (SECRETARIA DA CASA CIVIL, 2014). 
However, it also faces problems, particularly with regard to infrastructure, mobility, logistics, housing, and environmental sanitation. The adequate functioning of the MMP system is reflected in the quality of life of the population (SECRETARIA DA CASA CIVIL, 2014) and the demand for energy in the area. Table I presents a summary of the primary indicators of MMP, such as total area, total population, GDP, HDI, final energy consumption, energy consumption per capita, installed capacity for total electricity generation, and $\mathrm{CO} 2$ emissions per capita.

Table I - Profile and macroeconomic indicators of the MMP

\begin{tabular}{|c|c|c|}
\hline INDICADOR & VALUE & SOURCE \\
\hline Total area & $53.400 \mathrm{~km}^{2}$ & EMPLASA (2019) \\
\hline Total population & 32.629 .239 & SEADE (2019) \\
\hline $\begin{array}{c}\text { Total GDP at cur- } \\
\text { rent price }(\mathrm{R} \$ \\
1.000) \\
\end{array}$ & $\mathrm{R} \$ 1.669 .448 .647$ & IBGE (2016) \\
\hline Average MHDI & 0,75 & $\begin{array}{l}\text { Atlas Brasileiro do Desenvolvimento Hu- } \\
\text { mano (2010) }\end{array}$ \\
\hline $\begin{array}{l}\text { Final energy con- } \\
\text { sumption }\end{array}$ & 31,6 MTOE & SECRETARIA DE ENERGIA (2018) \\
\hline $\begin{array}{c}\text { Final energy } \\
\text { consumption per } \\
\text { capita }\end{array}$ & 0,97 TOE/hab & $\begin{array}{l}\text { SECRETARIA DE ENERGIA (2018); IBGE } \\
\text { (2016) }\end{array}$ \\
\hline $\begin{array}{l}\text { Total installed ca- } \\
\text { pacity }\end{array}$ & $4.064 \mathrm{MW}$ & $\begin{array}{l}\text { Authors from SECRETARIA DE ENERGIA } \\
\text { (2018) e BIG Aneel. }\end{array}$ \\
\hline $\begin{array}{l}\mathrm{CO}_{2} \text { emissions per } \\
\text { capita }\end{array}$ & $1,7 \mathrm{t} \mathrm{CO}_{2} / \mathrm{hab}$ & $\begin{array}{l}\text { SECRETARIA DE ENERGIA (2018); IBGE } \\
\text { (2016) }\end{array}$ \\
\hline
\end{tabular}

\section{Detailed assumptions for gathering information from the MMP Energy System}

The data analysis on the energy consumption for the 174 municipalities was carried out based on the information available in the Statistical Yearbook of Energy Sources by the municipality in the state of São Paulo between 2006 and 2017 (SECRETARIA DE ENERGIA, 2007-2018). The yearbooks contain information regarding the consumption of the following energy resources: electricity, NG, hydrated ethanol, and petroleum products (i.e., automotive gasoline, aviation gasoline, diesel oil, fuel oil, aviation kerosene, lighting kerosene, liquefied petroleum gas (LPG), coke, and asphalt).

The data on energy supply used in this study were collected from National Electrical Energy Agency (ANEEL), Generation Information Bank (BIG). Data required was installed capacity (CapInst) for electricity generation (inside the limits of the MMP 
region) until June 2019.

In order to determine the local energy potential of renewables in the MMP, the study considered the following energy resources: solar PV, water potential inventoried for SHPs in the MMP, and biogas (including the sewage sludge from the sanitation process ${ }^{1}$ ). However, a thorough analysis of the energy system of the region should also provide information on the various energy resources available in MMP (e.g., wind power for electricity production, biofuel production, biomass sources such as sugarcane sugar) as well as for the transformation centers, refineries, and petrochemical resources produced in the territory. However, this is outside the scope of this study and can be the focus of future studies. The results of the systematization of the data on electricity supply in MMP are presented in an aggregated form on the results section.

\section{Renewable energy resources: assumptions used to estimate the possible expansion of renewable energy supply in the MMP}

\section{Photovoltaic solar energy}

The potential generation of PV solar energy estimated for the MMP considered only distributed generation. In this sense, data from ANEEL (2019c) regarding the average installed capacity of PV plants in the region (2012-2018) were used to define the market expansion for this source. Thus, $97 \%$ of the micro- and mini-PV plants in the MMP were located in the residential and commercial sectors (ANEEL, 2019a); hence, the assessment of potential in this study is restricted to these two sectors.

The following data were used to calculate the expansion of PV supply: the average peak sun hours (HPS) of the MMP, which was calculated based on the number of hours of sunshine equivalent to a standard hour of $1,000 \mathrm{~W} / \mathrm{m} 2$; the conversion factor of the photovoltaic system (SFV), which included residential and commercial values of 4.04 $\mathrm{kWp}$ and $17.9 \mathrm{kWp}$, respectivley (BRASIL, 2019); and the potential market-residential rate, which as equivalent to $16 \%$ with $12,673,946$ consumer units or $0.5 \%$ with 810,542 consumer units (SECRETARIA DE ENERGIA, 2018).

\section{Hydraulic resources by SHP}

To determine the untapped potential of the hydraulic resources by SHP available in the MMP, we used hydraulic potentials inventoried database available on ANEEL's website. In this study, we analyzed only the potential of the MMP characterized as SHP, i.e., projects between $5 \mathrm{MW}$ and $30 \mathrm{MW}$ that are in the process of being granted to an interested entrepreneur, or that meet the available axis (i.e., without anyone applying

1- Other methodologies for calculating the estimated expansion of supply of biogas, solar, and hydro energy can be found in ENERGY RESEARCH COMPANY (EPE) / MINISTRY OF MINES AND ENERGY (MME; 2019) and in SÃO PAULO Secretariat of Environmental Infrastructure (SIA; 2013). 
for the permission). In addition, the study accounted for potential resources (partially completed) that had already been granted to some entrepreneurs, but which have not yet been built. Potentials smaller than $5 \mathrm{MW}$ SHP were excluded from the study; prior to the installation of such projects, there were no requirements in terms of ANEEL inventories or authorizations.

\section{Biogas produced from sludge}

The potential of biogas generation was estimated for the MMP region, not for each municipality. Data on the volume of sewage treated by the municipality in 2017 (unit: $1000 \mathrm{~m} 3$ /year) were collected from the National Sanitation Information System (SNIS). The population data for each MMP municipality was collected from 2017 at IBGE website. No data were found on the volume of sewage collected for the following municipalities: Embu, Natividade da Serra, Potim, and São José do Barreiro.

The volume of sewage treated by the municipality was added up, resulting in a total of 1,061,676,000 m3 sewage treated in the MMP per year. The density of water and sewage was considered the same because sanitary sewage is mainly composed of water ( $~ 99.8 \%$ of its volumetric composition), and $1 \mathrm{~m} 3$ of water is equivalent to $1 \mathrm{t}$ of water. Based on this assumption, the units were converted and the potential for energy generation was calculated using biogas from sewage sludge according to the methodology presented by SILVEIRA et al. (2015). They considered the biogas calorific value to be 23.3. $\mathrm{m} 3 ; 1 \mathrm{t}$ of sludge contained $70 \%$ volatile organic compounds, of which $40 \%$ were destroyed volatile solids and biogas production was considered to be $0.8 \mathrm{~m} 3 / \mathrm{kg}$ destroyed volatile organic compounds.

\section{Results}

\section{Energy demand in the MMP}

Figure I shows the evolution of the annual consumption (2006-2017) of electricity, NG, hydrated ethanol, and oil products in the MMP. In 2017, the MMP consumed 31.6 million tons of oil equivalent (MTOE), of which $\sim 50 \%$ was contributed by the consumption of oil products, followed by the consumption of electricity $(\sim 30 \%$ of demand), NG (16\%), and ethanol (8\%). According to the analysis and systematization of the data (2006-2017) obtained from the Statistical Yearbooks of Energy Sources by the Municipality (SECRETARIA DE ENERGIA, 2007-2018), energy consumption in the MMP increased by 30\% over the last decade, representing 73\% (31.6 MTOE/year) of the total consumption by the entire state of SP in 2017 (43.1 MTOE/year). 
Figure I - Evolution of energy consumption in the MMP from 2006 to 2017

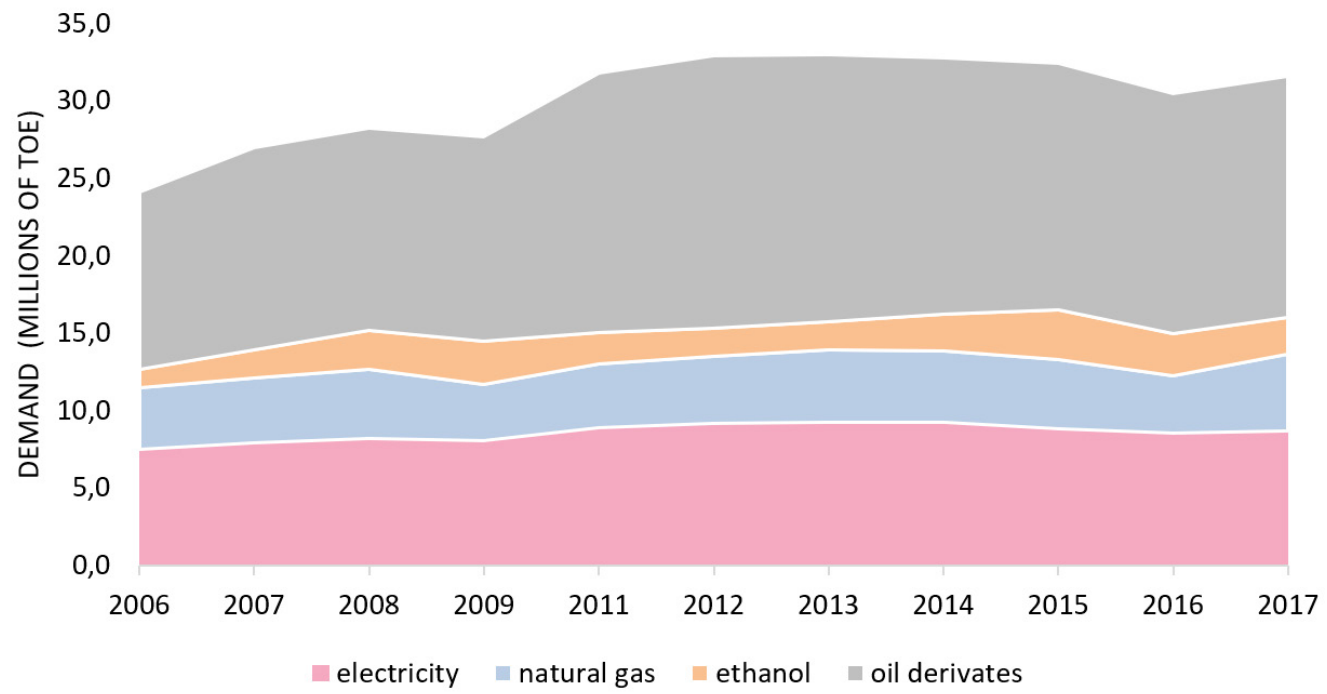

Source: Municipal Energy Yearbooks of the state of São Paulo (SECRETARIA DE ENERGIA, 2007-2018)

For the period considered, all sources showed a significant increase in demand; however, ethanol consumption showed the most significant increase (102\%; 1.22 MTOE), followed by the consumption of oil products, with an increase of $36 \%$ (4.1 MTOE). Derivatives consumed in the region represented $69 \%$ of the total consumption across the state of SP in 2017 (15.5 MTOE). In the last decade, the consumption of coke, gasoline, and aviation gasoline exhibited the highest growth in the region $(261.5 \mathrm{MTOE}, 62 \%$ or 2026.6 MTOE, and 61\% or 962.6 MTOE, respectively). Lighting kerosene, fuel oil, and asphalt exhibited the most remarkable decrease in consumption (98\% or $4.16 \mathrm{MTOE} /$ year, $73 \%$ or $360.12 \mathrm{MTOE} /$ year, and $50 \%$ or $147.1 \mathrm{MTOE} /$ year, respectively).

Figure II shows the energy consumption in the MMP by sector. In 2017, the highest levels of demand for energy were from the transportation sector, with $49 \%$ of the total consumption (15 MTOE), followed by the industrial sector (25\%; $7 \mathrm{MTOE})$, and the residential sector $(12 \% ; 3 \mathrm{MTOE})$. . Together, these three sectors accounted for $86 \%$ of total energy consumption in the MMP in 2017. 
Figure II - Energy Consumption in the MMP by sector.

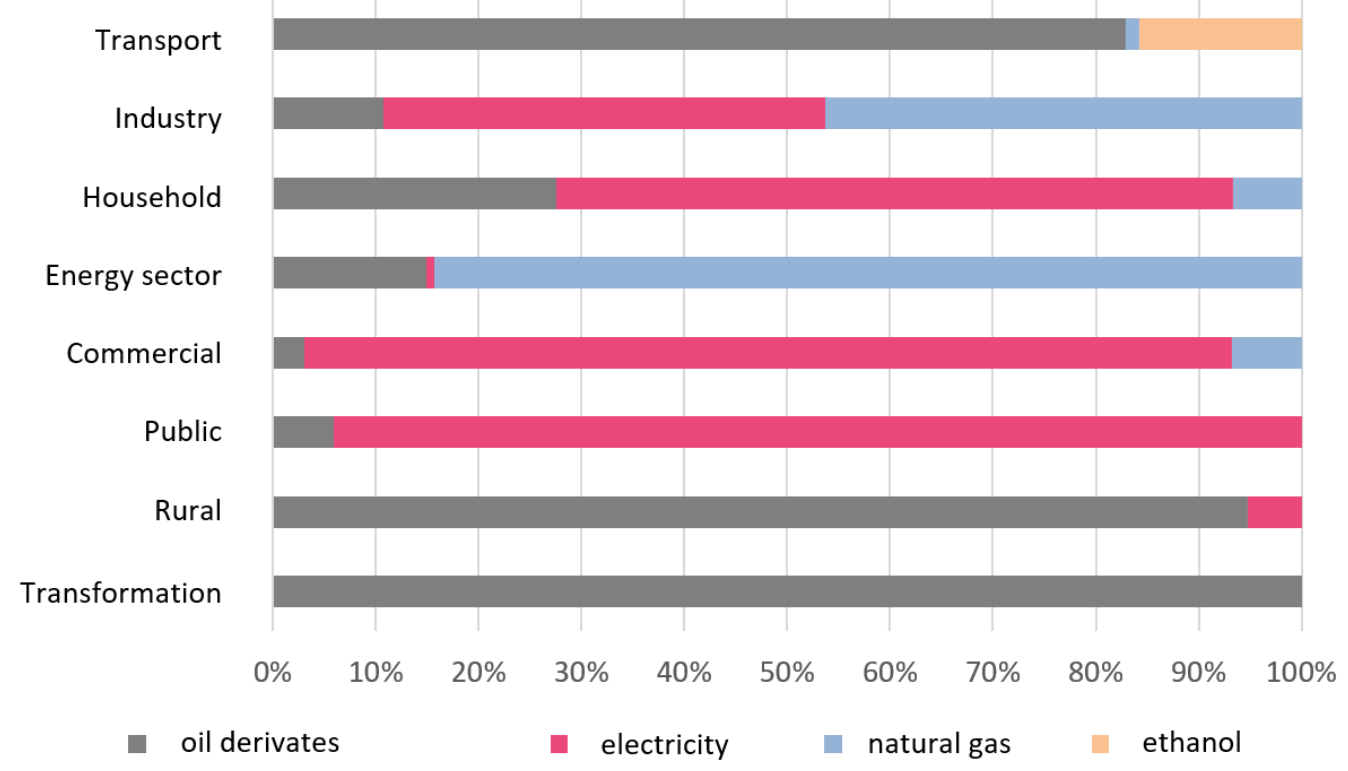

Source: Municipal Energy Yearbooks of the state of São Paulo (SECRETARIA DE ENERGIA, 2018).

Regarding the energy inputs associated with the consumption of oil products, automotive gasoline and diesel oil represented $69 \%(8,180,536.7$ TOE) of their total consumption. When extrapolating the consumption of oil products by energy input, it was observed that $82 \%$ (12.76 MTOE) of all oil products in the MMP in 2017 were consumed in the transport sector, followed by the residential $(7 \% ; 1.9 \mathrm{MTOE})$ and industrial $(6 \% ; 0.85$ MTOE) sectors; regarding ethanol consumption, $100 \%$ of the consumption presented in the energy annuals was attributed to the transport sector. It is important to highlight that this value is high given that annuals only report the consumption of hydrated ethanol. It is also worth mentioning that the consumption of anhydrous ethanol was not computed separately but was included in the consumption of automotive gasoline (27\% of the total).

In 2017, the consumption of NG in the MMP represented 90\% (4.9 MTOE) of the total consumption in the state of SP. The industrial sector consumed the highest amount of energy in the region. The consumption of $\mathrm{NG}$ for thermoelectric generation and cogeneration was classified as the energy sector demand because NG was used to generate electricity. Thermoelectric generation in 2017 was responsible for $9.4 \%$ of all the consumption of NG in the MMP $(0.46 \mathrm{TOE})$. Finally, regarding electricity consumption, MMP energy demand represented 78\% (8.7 MTOE) of total state consumption in 2017. The industrial, residential, and commercial sectors constituted the majority share of the final electricity consumption.

Regarding the distribution of the MMP RES and nonrenewable consumption in 2017, it was concluded that, on the demand side, there was a predominance of the 
consumption of fossil energy sources (70\% or 22.7 MTOE of consumption), whereas the consumption of RES represented 30\% (9.4 MTOE of the final energy demand of the MMP). These results are relevant when formulating energy planning policies aimed at reducing fossil fuel consumption as they reflects the relevance of understanding how energy is used and the demand side potentialities. Finally, Figure III presents the history of CO2 emissions in the MMP from 2008 to 2017. There was a relationship between the fluctuations in the demand of each energy source and the increase/decrease in emissions.

Figure III - Evolution of CO2 emissions associated with energy consumption in the MMP.

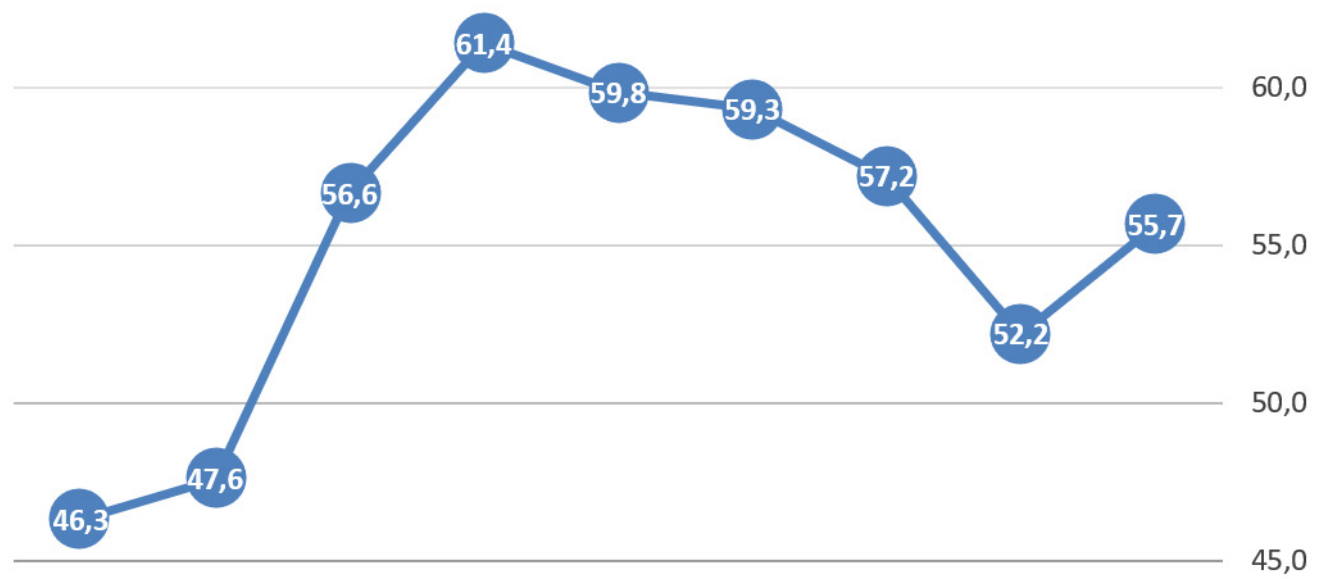

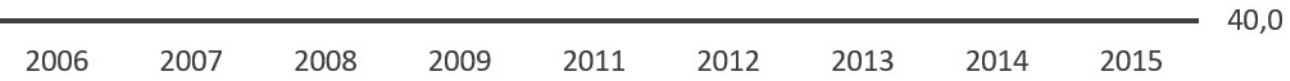

Source: Municipal Energy Yearbooks of the state of São Paulo (SECRETARIA DE ENERGIA, 20072018).

It should be noted that the $\mathrm{CO} 2$ emissions reflect only the consumption of the primary energy sources in the 174 municipalities of the MMP (such as electricity, ethanol, oil products, and NG). These data were provided by the SECRETARIA DE ENERGIA of the state of SP and were not collected by this study. According to the institution, FER contributions (e.g., bagasse, firewood, and charcoal) were considered null since photosynthesis removes an equivalent amount of carbon released during the combustion of these sources from the atmosphere. Thus, the result of the total emissions for the MMP considers only the demand for the following energy sources: NG, automotive and aviation gasoline, diesel oil, fuel oil, illumination, aviation kerosene, LPG, petroleum coke, and asphalt. 


\section{Energy Supply in the MMP}

Table II shows the CapInst values for electricity generation in the MMP by enterprise, energy resource used, installed capacity $(\mathrm{kW})$, and the number of generating units.

Table II - Installed capacity for electricity generation in MMP region (until 2019)

\begin{tabular}{|l|l|l|}
\hline Renewable sources & CapInst (kW) & Number of plants \\
\hline Big Hydroelectric power plant & 1.306 .860 & 13 \\
Small hydroelectric plant & 164.998 & 16 \\
Micro and mini hydroelectric power plant & 20.704 & 19 \\
Wind power plant & 2 & 1 \\
EOL micro and mini generation plants & 34 & 5 \\
\hline Photovoltaic solar power station & 1.236 & 8 \\
UFV micro and mini-generation plants & 28.530 & 4949 \\
\hline Thermoelectric plant - sugarcane bagasse & 358.241 & 24 \\
Thermoelectric plant - biogas & 67.766 & 8 \\
Thermoelectric plant - biomass & 60.007 & 4 \\
\hline Total & $\underline{2.008 .378}$ & $\underline{5047}$ \\
\hline Fossil sources & $\underline{\mathbf{C ~ a ~ p ~ I ~ n ~ s ~ t ~}}$ & Number of plants \\
\hline & $\underline{\mathbf{( k W )}}$ & \\
Thermoelectric plant - process heat & 24.400 & 1 \\
Thermal power plant - coal - RSU & 2.700 & 1 \\
Thermoelectric plant - refinery gas & 204.730 & 3 \\
Thermal power plant - natural gas & 980.679 & 45 \\
Thermoelectric plant - fuel oil & 213.358 & 5 \\
Thermal power plant - diesel & 544.961 & 514 \\
Thermoelectric plant - other petroleum products & 85.188 & 7 \\
UTE micro and mini generation plants & 275 & 3 \\
\hline Total & 2.056 .291 & 579 \\
\hline Total Renewables and Fossils & 4.064 .669 & 5626 \\
\hline
\end{tabular}

Source: BIG (ANEEL, 2019a).

In 2019, in the MMP, there were $4 \mathrm{GW}$ of CapInst for electricity generation corresponding to $17 \%$ of CapInst in the state of SP (23 GW; SECRETRARIA DE ENERGIA, 2018). However, it is to be noted that the base year data for decentralized CapInst corresponds to the year 2019, whereas the others correspond to the year 2017. However, it is 
clear that of all the CapInst of the thermoelectric systems using fossil resources installed in the state, $90 \%(2 \mathrm{GW})$ were located in the MMP region. This is an interesting finding to be considered when planning policy innovations to substitute fossil fuels, thereby reducing emissions, once MMP inhabitants can feel the impact of the use of such fuels on public health.

The most important type of powerplants in the MMP is thermoelectric energy, with $63 \%(2.5 \mathrm{GW})$ of CapInst, of which the thermal power plants that use NG as fuel $(1.2 \mathrm{GW})$ are a majority (Figure IV). The second type of powerplants with the highest CapInst is hydroelectric power (32\%), which is also the energy resource that holds the largest CapInst in the region. The hydro resource has an installed capacity of $1.5 \mathrm{GW}$ (Figure IV).

Figure IV - Installed capacity of energy generation plants in MMP according to the types of ventures and energy resources used.

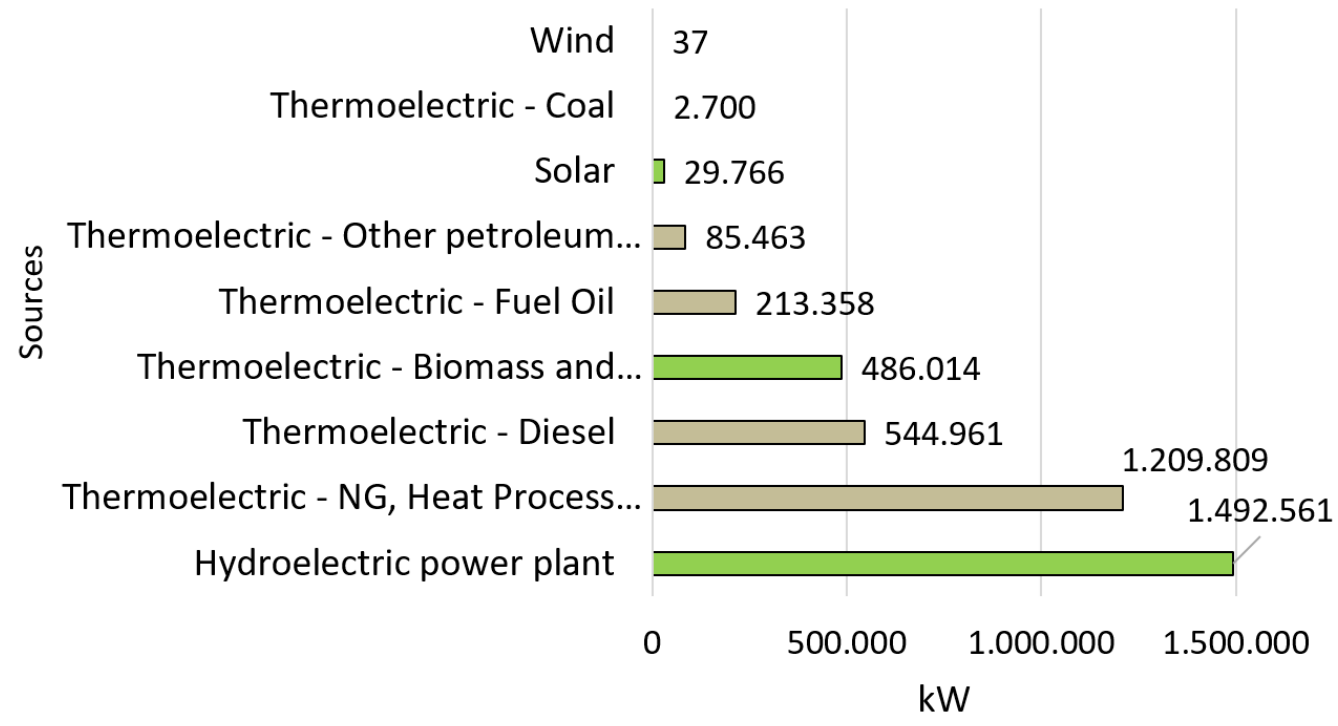

Source: BIG (ANEEL, 2019a).

Of the 174 municipalities, 4 cities (Paulínia, 3\% of total CapInst; Jacareí, 6\% of total CapInst; São Paulo, 22\% of total CapInst; and Cubatão, 30\% of total CapInst) collectively contributed with $62 \%$ of the total CapInst for the region $(2,510,432 \mathrm{~kW}$ of the $4,035,740 \mathrm{~kW})$. Finally, on the supply side and considering only CapInst for electricity generation, the MMP region presented a balanced share of installed capacity between the use of fossil resources (51\%) and renewable resources (49\%). The largest CapInst energy resources in the region are the 13 large hydroelectric plants (HPP; Table 1), corresponding to $1,306 \mathrm{MW}$ and $32 \%$ of the energy supply of the MMP.

The municipality that has the largest Hydro power plant is Cubatão (Henry Borden 
power plant). It is important to clarify that the fact that MMP has approximately $4 \mathrm{GW}$ of CapInst does not mean that this entire potential has been explored in the region. In fact, the largest plant in the region (Henry Borden with $889 \mathrm{MW}$ ) has been operating since 1992 (following the conditions established in the Joint Resolution SMA/SES 03/92 of 10/04/92, updated by Resolution SMA-SSE-02 of 19/02/2010) with only 25\% of its potential. This restriction aims to reduce the accumulation of pollution in the Billings Dam and its reservoir (which supplies the city of São Paulo). In this sense, this study has demonstrated the need for reconciliation between the different types of planning and policies, given that the treatment of complex problems, such as the energy system itself, demands the development of creative, integrated, and diversified solutions that are both multisectoral and multilevel. The lack of coherence or non-compliance/implementation of environmental policies may negatively impact the optimal use of infrastructure facilities for electricity generation, as is the case with the Henry Borden Power Plant.

Finally, regarding the possibilities of MMP RES supply exploitation of solar, hydro, and sewage biogas resources, the results indicate a potential for an installed capacity of 8,264.4 MW. For hydro, the results indicated a potential of 171.02 MW (installable capacity), which could still be exploited to locally generate electricity. Finally, in sewage biogas, a total of $175.7 \mathrm{MW}$ of installable capacity was found. Therefore, the study concluded that it would be possible to increase the region energy supply locally by approximately $112 \%(\sim 8611 \mathrm{MW})$. So, there is an untapped potential remarkably greater than the current energy generation.

It should be noted that this result considers the potential of only three types of resources: solar, SHP, and biogas. A complete analysis of the various energy resources, such as wind and biomass, is still lacking. Plus, we did not consider a projection of the data used in the long term; consequently, the result could be under or overestimated. It is worth to mention that the best way to estimate the potentials for energy exploration is to collect primary data. However, this paper used secondary and aggregated data for the region.

\section{Conclusions}

A detailed analysis of energy city systems is important for the elaboration of efficient public policies proposals. It would be possible to increase the installed capacity of the region by $\sim 112 \%$; i.e., $4,547 \mathrm{MW}$ could be added to the MMP, an untapped potential greater than what is currently installed.

Regarding the description of the MMP energy system, the following results stem out from the paper; whereas they also provide answers to the guiding questions of this research. The most consumed energy resources in the region (in the study period) were oil derivates ( $\sim 50 \%$ of the final energy demand), of which gasoline and diesel consumption constituted $\sim 35 \%$ each of the final demand for oil products, electricity $(30 \%)$, and natural gas $(15 \%)$. The most demanding economic sectors are the transport, industry, and household sectors, constituting 49\%, 25\%, and 12\% of the final energy demand, respectively. 
The results of this study highlight the importance of research on urban energy systems for the proposition of adequate and evidence-based energy and environmental policies that seek to actually propose measures and strategies to mitigate global warming. Current Brazilian Energy Planning policies, with focus on the provision of electricity through the expansion of the hydroelectric and thermoelectric system, do not include an analysis of energy end uses. The study also points out that the most significant share of fossil energy consumption is demand-driven (70\% of final consumption) and not supplydriven. This is a breakthrough result, and that's why an effective methodology for local governments to adapt to climate change and mitigate its effects, it's through a better understanding of their urban energy systems via the development of improved urban energy planning policies and practices. To do so, the first step is to conduct research and data surveys, measurements, and verifications, without which the planning process (i.e., the anticipation of future problems) becomes inefficient.

Thus, in this study, we used the concepts of energy governance and multilevel governance as a starting point to understand the policies of the energy system. Different studies on multilevel governance emphasize that climate change must and can be addressed at various government and social levels. If local governments are willing to participate actively in sustainable initiatives, they should collect data and develop analysis of their urban energy systems. The climate initiatives and actions carried out in cities could potentially increase the confidence of regional and national governments to set more ambitious targets for reducing $\mathrm{GHG}$ emissions and pursuing sustainable low-carbon strategies. These policy dynamics between cities and other governmental levels are of crucial importance in the global response to climate change and need to be studied in more detail. Future studies may be directed toward the measurement and verification of local planning processes and their implications at both regional and national levels.

\section{Acknowledgments}

The authors acknowledge the financial support received from São Paulo Research Foundation (FAPESP), Process: 2015/03804-9. Benites-Lazaro Lira Luz also acknowledges [FAPESP; process 2017/17796-3 and process 19/24479-0], and Lampis, Andrea acknowledges [FAPESP; process no 2018/17626-3] for the support.

\section{References}

ALLEN, A; DAVILA, J.; HOFMANN, P. Agua y saneamiento en la interfaz periurbana: Un vistazo a cinco estudios de caso. Cuadernos del CENDES, v. 22, n. 59, p. 23-44, 2005.

ANEEL, 2019a. Banco de Informações de Geração (BIG) website. Disponível em:<http:// 
www2.aneel.gov.br/aplicacoes/capacidadebrasil/capacidadebrasil.cfm $>$. Ultimo acesso em: 20/08/19.

ANEEL, 2019b. Outorgas e Registros de geração website. Disponível em: < http://www.aneel. gov.br/outorgas $>$. Ultimo acesso em: 20/08/19.

ANEEL, 2019c. Unidades consumidoras com Geração Distribuída. Disponível em: < http:// www2.aneel.gov.br/scg/gd/gd.asp>. Último acesso em 20/08/2019.

ANEEL. Nota Técnica n 0056/2017-SRD/ANEEL: Atualização das projeções de consumidores residenciais e comerciais com microgeração solar fotovoltaicos no horizonte 2017-2024. Agência Nacional de Energia Elétrica, 2017.

BALAT, M. Usage of energy sources and environmental problems. Energy exploration \& exploitation, 23(2), p.141-167, 2005.

BAZILIAN, M., et al. Energy governance and poverty.Energy Research $\mathbb{\&}$ Social Science, 1, p. 217-225, 2014.

BENITES-LAZARO, L. L., et al. Governança e desenvolvimento sustentável: a participação dos stakeholders locais nos projetos de Mecanismos de Desenvolvimento Limpo no Brasil.Cuadernos de Geografía-Revista Colombiana de Geografía, 27(2), p. 227-241, 2018b. http://dx.doi. org/10.15446/rcdg.v27n2.66336

BENITES-LAZARO,L. L., et.al. Topic modeling method for analyzing social actor discourses on climate change, energy and food security.Energy research $\mathbb{E}$ social science,45, p. 318-330, 2018a.

BEVIR, M. Governance: A very short introduction. Oxford: Oxford University Press, 2012.

BRASIL. Agência Nacional de Energia Elétrica (ANEEL). Unidades Consumidoras com Geração Distribuída. Disponível em: < http://www2.aneel.gov.br/scg/gd/gd.asp > Acesso em: 13 de ago.2019

BRASIL. Empresa de Pesquisa Energética. Inserção da Geração Fotovoltaica Distribuída no Brasil: Condicionantes e Impactos. Rio de Janeiro, RJ, 2014.

BRASIL. Empresa de Pesquisa Energética. Modelo de Mercado da Micro e Minigeração Distribuída (4MD): Metodologia: Versão PDE 2027. Rio de Janeiro, RJ, 2018.

CARRASCO, J. M. et al. Power-Electronic Systems for the Grid Integration of Renewable Energy Sources: A Survey. IEEE TRANSACTIONS ON INDUSTRIAL ELECTRONICS, v. 53, n. 102, p. 1002-1016, 2004.

COLLAÇO, F. M. A. et al. The dawn of urban energy planning - synergies between energy and urban planning for São Paulo (Brazil) megacity. Journal of Cleaner Production, v. 215, p. 458-479, 2019a. 
COLlAÇO, F. M. A. et al. What if São Paulo (Brazil) would like to become a renewable and endogenous energy -based megacity? Renewable Energy, v. 138, p. 416-433, 2019b.

DAVIS, M., BENZIE, M., BARROTT, J. Introducing the Transnational Climate Impacts Index: indicators of country-level exposure - methodology report. Stockholm Environment Institute, 2016.

DI GREGORIO, Monica et al. Multi-level governance and power in climate change policy networks. Global Environmental Change, v. 54, p. 64-77, 2019.

ELBARADEI, M. A global agency is needed for the energy crisis. Financial Times, p.23, 2008.

EMPLASA, 2019. Website EMPLASA. Dados sobre a MMP. Disponível em: < https://emplasa.sp.gov.br/MMP > . Ultimo acesso em: 20/08/19.

EMPLASA. Macrometrópole Paulista. 1a. ed. São Paulo: Emplasa - Empresa Paulista de Planejamento Metropolitano SA, 2012.

EPE - EMPRESA DE PESQUISA ENERGÉTICA. BEN 2018 - Relatório Sintese. Rio de Janeiro: 2018.

EPE - EMPRESA DE PESQUISA ENERGÉTICA. INFORME À IMPRENSA Plano Decenal de Expansão de Energia - PDE 2027. Rio de Janeiro: 2018.

Escribano, G. Fragmented energy governance and the provision of global public goods. Global Policy, 6(2), 97-106, 2015.

FUDGE, Shane; PETERS, Michael; WOODMAN, Bridget. Local authorities as niche actors: The case of energy governance in the UK. Environmental Innovation and Societal Transitions, v. 18, p. 1-17, 2016.

FUHR, Harald; HICKMANN, Thomas; KERN, Kristine. The role of cities in multi-level climate governance: local climate policies and the $1.5 \mathrm{C}$ target. Current opinion in environmental sustainability, v. 30, p. 1-6, 2018.

GEELS, Frank W.; KEMP, René. The multi-level perspective as a new perspective for studying socio-technical transitions. , in Geels et al (Eds) Automobility in Transition? A socio-Technical Analysis of Sustainable Transport, Routledge, New York, pp. 49-79.2012

GIROTTI, C. Modelagem dos parâmetros da forma urbana para a maximização de geração de energia solar fotovoltaica no ambiente urbano em adensamento e verticalização: estudo de caso do Belenzinho, em São Paulo. (Dissertação de Mestrado). Escola Politécnica da USP. Departamento de Engenharia de Construção Civil, 118 p., 2019.

GOLDEMBERG, J., LUCON, O. Energia Meio Ambiente e Desenvolvimento. 3 edição, 400p., EDUSP: 2012.

HEUBAUM, H., BIERMANN, F. Integrating global energy and climate governance: The chan- 
ging role of the International Energy Agency. Energy Policy, 87, p. 229-239, 2015.

IBGE- INSTITUTO BRASILEIRO DE GEOGRAFIA E ESTATÍSTICA, 2016. Website IBGE. Produto Interno Bruto dos municipios em 2016. Disponível em: <ttps://www.ibge. gov.br/estatisticas/economicas/contas-nacionais/9088-produto-interno-bruto-dos-municipios. html?t $=$ publicacoes $>$. Ultimo acesso em: 20/08/19

IBGE- INSTITUTO BRASILEIRO DE GEOGRAFIA E ESTATÍSTICA. Brasil em Síntese | São Paulo | São Paulo | Panorama. IBGE, 2010.

IEA - INTERNATIONAL ENERGY AGENCY, 2018. IEA Website, World Energy Outlook 2018.Disponivel em: < https:/www.iea.org/newsroom/news/2018/november/world-energy-outlook-2018-examines-future-patterns-of-global-energy-system-at-a-t.html $>$. Ultimo acesso em 20/08/19.

IEA - INTERNATIONAL ENERGY AGENCY. Global Energy \& CO2 Status Report: Emissions. Paris: OECD/IEA, 2019.

IEA - INTERNATIONAL ENERGY AGENCY.Energy and climate change: World energy outlook special report.Paris: OECD/IEA, 2015. Retrieved from: www.iea.org

ITAIPU, 2015. Website da Usina de Itaipu. Disponível em: < https://www.itaipu.gov.br/sala-de-imprensa/perguntas-frequentes $>$. Ultimo acesso em: 08/12/15.

JACOBI, P. R.; TRANI, E. Planejando o futuro hoje: ODS 13, Adaptação e Mudanças Climáticas em São Paulo. São Paulo: IEE-USP, 2019.

JÄNICKE, Martin; QUITZOW, Rainer. Multi $\square$ level Reinforcement in European Climate and Energy Governance: Mobilizing economic interests at the sub־national levels. Environmental Policy and Governance, v. 27, n. 2, p. 122-136, 2017.

KERN, Kristine; BULKELEY, Harriet. Cities, Europeanization and multi $\square$ level governance: governing climate change through transnational municipal networks. JCMS: Journal of Common Market Studies, v. 47, n. 2, p. 309-332, 2009.

LEHTOLA, T.; ZAHEDI, A. Solar energy and wind power supply supported by storage technology: A review. Sustainable Energy Technologies and Assessments, v. 35, n. May, p. 25-31, 2019.

LIANG, X.; MAZIN, H. E.; REZA, S. E. Probabilistic generation and transmission planning with renewable energy integration. 2017 IEEE/IAS 53rd Industrial and Commercial Power Systems Technical Conference (I\&CPS), p. 1-9, 2017.

LOVINS, A. B. Reinventando o fogo: Soluções ousadas de negócios na nova era da energia. $1^{\circ}$ ed. São Paulo: Editora Cultrix, 2013.

MARINS, K. R. D. C. C. A method for energy efficiency assessment during urban energy planning. Smart and Sustainable Built Environment, v. 3, n. 2, p. 132-152, 2014. 
MARINS, K. R. D. C. C.; ROMÉRO, M. DE A. Urban and Energy Assessment from a Systemic Approach of Urban Morphology, Urban Mobility, and Buildings: Case Study of Agua Branca in Sao Paulo. Journal of Urban Planning and Development, v. 140, n. 3, p. 402-408, 2014.

MELICA, Giulia et al. Multilevel governance of sustainable energy policies: The role of regions and provinces to support the participation of small local authorities in the Covenant of Mayors. Sustainable cities and society, v. 39, p. 729-739, 2018.

NOTTON, G. et al. Intermittent and stochastic character of renewable energy sources: Consequences, cost of intermittence and benefit of forecasting. Renewable and Sustainable Energy Reviews, v. 87, n. February, p. 96-105, 2018.

PEREIRA, E. B. et al. Atlas brasileiro de energia solar (2a edição). São José dos Campos: Inpe, 2017.

PRASAD, A. A.; TAYLOR, R. A.; KAY, M. Assessment of solar and wind resource synergy in Australia. Applied Energy, v. 190, p. 354-367, 2017.

QGIS, 2019. Website. Disponivel em: < https:/www.qgis.org/en/site/>. Ultimo acesso em: 20/08/19.

REHMAN, M. U., RASHID, M. Energy consumption to environmental degradation, the growth appetite in SAARC nations.Renewable energy,111, p. 284-294, 2017.

RHODES, R. The new governance: governing without government. Political Studies, 46, p. 652-667,1997.

ROSLAN, M. F. et al. Microgrid control methods toward achieving sustainable energy management. Applied Energy, v. 240, n. October 2018, p. 583-607, 2019.

SÃO PAULO. Secretaria de Infraestrutura de Ambiente (SIA). Energia Solar Paulista: levantamento do potencial. 2013. Disponível em: < http://dadosenergeticos.energia.sp.gov.br/ portalcev2/intranet/BiblioVirtual/renovaveis/atlas_energia_solar.pdf $>$ SEADE, 2019. Website SEADE. Analise de dados estatísticos, dados populacionais. Disponível em: < http://www. imp.seade.gov.br/frontend/\#/tabelas $>$. Acesso em: 21/08/19

SCHAKEL, Arjan H.; HOOGHE, Liesbet; MARKS, Gary. Multilevel governance and the state. The Oxford handbook of transformations of the state, p. 269-285, 2015.

SECRETARIA DA CASA CIVIL. Plano de Ação da Macrometrópole Paulista 2013-2040: política de desenvolvimento da macrometrópole. Volume 1, ed. São Paulo: EMPLASA, 2014.

SECRETARIA DE ENERGIA. Anuário Estatístico de Energéticos por Município no Estado de São Paulo - 2008 ano base 2007. Governo do Estado de São Paulo, São Paulo: 2008.

SECRETARIA DE ENERGIA. Anuário Estatístico de Energéticos por Município no Estado de São Paulo - 2009 ano base 2008. Governo do Estado de São Paulo, São Paulo: 2009. 
SECRETARIA DE ENERGIA. Anuário Estatístico de Energéticos por Município no Estado de São Paulo - 2010 ano base 2009. Governo do Estado de São Paulo, São Paulo: 2010.

SECRETARIA DE ENERGIA. Anuário Estatístico de Energéticos por Município no Estado de São Paulo - 2011 ano base 2010. Governo do Estado de São Paulo, São Paulo: 2011.

SECRETARIA DE ENERGIA. Anuário Estatístico de Energéticos por Município no Estado de São Paulo - 2012 ano base 2011. Governo do Estado de São Paulo, São Paulo: 2012.

SECRETARIA DE ENERGIA. Anuário Estatístico de Energéticos por Município no Estado de São Paulo - 2013 ano base 2012. Governo do Estado de São Paulo, São Paulo: 2013.

SECRETARIA DE ENERGIA. Anuário Estatístico de Energéticos por Município no Estado de São Paulo - 2014 ano base 2013. Governo do Estado de São Paulo, São Paulo: 2014.

SECRETARIA DE ENERGIA. Anuário Estatístico de Energéticos por Município no Estado de São Paulo - 2015 ano base 2014. Governo do Estado de São Paulo, São Paulo: 2015.

SECRETARIA DE ENERGIA. Anuário Estatístico de Energéticos por Município no Estado de São Paulo - 2016 ano base 2015. Governo do Estado de São Paulo, São Paulo: 2016.

SECRETARIA DE ENERGIA. Anuário Estatístico de Energéticos por Município no Estado de São Paulo - 2017 ano base 2016. Governo do Estado de São Paulo, São Paulo: 2017.

SECRETARIA DE ENERGIA. Anuário Estatístico de Energéticos por Município no Estado de São Paulo - 2018 ano base 2017. Governo do Estado de São Paulo, São Paulo: 2018.

SECRETARIA DE ENERGIA. Energia Solar Paulista, levantamento do potencial. Governo do Estado de São Paulo, São Paulo: 2013

SECRETRARIA DE ENERGIA. Balanço Energetico do Estado de São Paulo 2018 ano base 2017. Governo do Estado de São Paulo, São Paulo: 2018.

SELLERS, JEFFEREY AND KWAK, SUN-YOUNG (2011) 'State and Society in Local Governance: Lessons From a Multilevel Comparison', International Journal of Urban and Regional Research, 2011.

SILVEIRA, B. et al. Guia Tecnica de Aproveitamento de Biogas em Estatações ed Tratamento de Esgoto, 2015.

SOARES, R. S. A difusão da Geração Distribuída Fotovoltaica na Macrometrópole Paulista. Dissertação (Mestrado em Ciências). Programa de Pós-graduação em Energia, Instituto de Energia e Ambiente da Universidade de São Paulo, p. 152, 2019.

SOVACOOL, B., FLORINI, A. Examining the complications of global energy governance.Journal of Energy \& Natural Resources Law.;30(3),p. 235-263, 2012.

UNITED NATIONS HABITATS. New Urban Agenda. United Nations, 2017. 
URRY, J. Consuming the planet to excess.Theory, Culture \& Society,27(2-3), p. 191-212, 2010.

VAN DE GRAAF, T.; COLGAN, J. Global energy governance: a review and research agenda. Palgrave Communications, 2(1), 2016.

VAN KERSBERGEN, K., VAN WAARDEN, F. 'Governance'as a bridge between disciplines: Cross $\square$ disciplinary inspiration regarding shifts in governance and problems of governability, accountability and legitimacy. European journal of political research, 43(2), p. 143-171, 2004.

WEBB, J.; HAWKEY, D.; TINGEY, M. Governing cities for sustainable energy: The UK case. Cities, v. 54, p.

WESTMAN, Linda Katrin; BROTO, Vanesa Castán; HUANG, Ping. Revisiting multi-level governance theory: Politics and innovation in the urban climate transition in Rizhao, China. Political Geography, v. 70, p. 14-23, 2019. 
Flávia Mendes de Almeida Collaço

$\square$ flavia.collaco@usp.br

ORCiD: https://orcid.org/0000-0003-4277-9043

\title{
Raiana Schirmer Soares
}

$\square$ raianaschirmer@usp.br

ORCiD: https://orcid.org/0000-0003-2551-1440

\section{João Marcos Mott Pavanelli}

$\square$ joaomarcos@usp.br

ORCiD: https://orcid.org/0000-0002-6330-9799

\section{Lira Luz Benites Lázaro}

ఐ1benites@usp.br

ORCiD: https://orcid.org/0000-0001-6587-1497

\section{Guilherme Massignan Berejuk}

ఐberejuk@usp.br

ORCiD: https://orcid.org/0000-0001-5162-1040

\author{
Andrea Lampis \\ ๑alampis@usp.br \\ ORCiD: https://orcid.org/0000-0002 1561-5409
}

\section{Célio Bermann}

$\square$ cbermann@iee.usp.br

ORCiD: https://orcid.org/0000-0002-1759-7523

How to cite: COLLAÇO, F. M. A; SOARES, R.S; PAVANELLI, J. M. M; BENITES-LAZARO, L. L; BEREJUK, G. M; LAMPIS, A; BERMANN. Understanding the Energy System of the Paulista Macrometropolis: a fisrt step for local action in Climate Change. Ambiente \& Sociedade. São Paulo, v. 23, p. 1-23, 2020. 


\title{
Identificação do Sistema Energético da Macrometrópole Paulista: primeiro passo para atuação local em Mudanças Climáticas
}

\author{
Flávia Mendes de Almeida Collaço \\ Raiana Schirmer Soares \\ João Marcos Mott Pavanelli \\ Lira Luz Benites-Lazaro \\ Guilherme Massignan Berejuk \\ Andrea Lampis \\ Célio Bermann
}

São Paulo. Vol. 23, 2020

Tema em destaque:

Urbanização, Planejamento e Mudanças Climáticas
Resumo: Este artigo analisa a oferta e demanda de energia e investiga as opções de aproveitamento de recursos energéticos locais da Macrometrópole Paulista a partir de fontes renováveis. Para tanto, foi conduzido um estudo abrangendo os 174 municípios da macrometrópole para identificar o Sistema de Energia da região, através do levantamento dos dados históricos sobre consumo e oferta de energia (2006-2017) e de emissões de $\mathrm{CO} 2$ decorrentes. Resultados do estudo indicam que a região consumiu em 2017, 73\% da demanda total por energia do estado de São Paulo e possui, dentro de seus limites municipais, cerca de 17\% da capacidade instalada total para geração de eletricidade do estado. Ainda, seria possível aumentar em $112 \%$ a capacidade instalada para geração de eletricidade na região. Conclui-se que a compreensão dos sistemas energéticos locais é indispensável para a formulação de políticas públicas coerentes e integradas, necessárias ao enfrentamento das mudanças climáticas.

Palavras-chave: Sistema energético;Macrometrópole Paulista; Mudanças Climáticas; Governança Energética.

Como citar: COLLAÇO, F. M. A; SOARES, R.S; PAVANELLI, J. M.; BENITES-LAZARO, L. L; BEREJUK, G. M; LAMPIS, A; BERMANN, C. Identificación des Sistema Energético del Macrometropole Paulista: primer passo para la accion local en Cambio Climático. . Ambiente $\mathbb{\&}$ Sociedade. São Paulo, v. 23, p. 1-24, 2020. 


\title{
Identificación del Sistema Energético delMacrometrópole Paulista: primer paso para laacción local en Cambio Climático
}

\author{
Flávia Mendes de Almeida Collaço \\ Raiana Schirmer Soares \\ João Marcos Mott Pavanelli \\ Lira Luz Benites-Lazaro \\ Guilherme Massignan Berejuk \\ Andrea Lampis
}

São Paulo. Vol. 23, 2020

Tema en Destaque:

Urbanización, $\mathrm{Pl}$ -

anificación y Cambio

Climático
Resumen: Este artículo analizala oferta y la demanda de energía, así como las opciones para aprovechar el potencial energético local en la Macrometrópolis Paulista con base en el uso de fuentes renovables. Se realizó un estudio que abarca los 174 municipios de la Macrometrópolis para identificar el Sistema de Energía de esa región mediante la construcción de un banco de datos sobre el consumo y el suministro de energía (2006-2017), así como sobre las emisiones de CO2. Los resultados indican que en 2017 la región consumió el 73\% de la demanda total de energía del estado de São Paulo y posee, dentro de sus límites administrativos, alrededor del $17 \%$ de la capacidad instalada total para la generación de electricidad del estado. Sin embargo, sería posible aumentar en un $112 \%$ dicha capacidad instalada. Se concluye que la comprensión de los sistemas energéticos locales es indispensable para la formulación de políticas públicas coherentes e integradas, necesarias para hacer frente al cambio climático.

Palabras-clave: Manglares; Fitosociología; Indústria del petróleo; Vulnerabilidad socioambiental; Interdisciplinariedad.

Como citar: COLLAÇO, F. M. A; SOARES, R.S; PAVANELLI, J. M. M; BENITES-LAZARO, L. L B; BEREJUK, G. M; LAMPIS, A; BERMANN, C. Identificación des Sistema Energético del Macrometropole Paulista: primer passo para la accion local en Cambio Climático. Ambiente $\&$ Sociedade. São Paulo, v. 23, p. 1-23, 2020. 